ノ-卜

日本の主要イチゴ品種を識別するマルチプレックス PCR プライマーセットの開発 田㟝公久 ${ }^{1,2)} \cdot$ 柏谷祐樹 1,2$) \cdot$ 小林俊一 ${ }^{1)} \cdot$ 天谷正行 ${ }^{1)}$

1) 杤木県農業試験場, 宇都宮市, ₹ 320-0002

2) 現 : 芳賀農業振興事務所, 真岡市, $=321-4305$

\title{
Development of multiplex PCR primer sets for identification of major strawberry (Fragaria $\times$ ananassa Duchesne) cultivars in Japan
}

\author{
Kimihisa Tasaki ${ }^{1,2)}$, Yuuki Kashiwaya ${ }^{1,2)}$, Shun-ichi Kobayashi ${ }^{1)}$ and Masayuki Amagai ${ }^{1)}$ \\ ${ }^{1)}$ Tochigi Prefectural Agricultural Experiment Station, Ustunomiya 320-0002, Japan \\ ${ }^{2)}$ Present address: Haga Agricultural Promotion Office, Moka 321-4305, Japan \\ キーワード \\ イチゴ，品種識別， RAPD， STS 化，マルチプレックス PCR
}

\section{1. 緒 言}

日本国内に拈けるイチゴ生産量は，190,600 t と世界第 8 位であり（2006 年度 FAO 調べ), 最重要な園芸品目で ある. 品種育成は，主に国公立研究機関抏よび種苗会社 によって行われて招り，1981-2007年までに 154 品種が 登録されている(農林水産省品種登録ホームページ). 現 在, 作付されている上位 8 品種は, ‘とち拈とめ’ (32.7\%), ‘さが注のか’ (16.7\%), 福岡 S6 号 (あまおう)’ (11.5\%), ‘さちのか’ (10.8\%)，“紅汇っぺ” (6.8\%)，“とよのか’ $(5.9 \%)$ ，‘章姫’ (5.1\%), ‘女峰’ (1.4\%) であり，全作 付面積の $90.9 \%$ を占めている（2007 年度 JA 全農調べ）。

近年, 国内育成品種が無許可で国外へ流出し，栽培さ れて收穫物が輸入される育成者権侵害の事例がイグサ, インゲンマメ，イチゴ等で報告されている（竹次 2004）. このような違法農産物を検査する際, DNA マーカーによ る品種識別は，客観的かつ簡易に判定することができる ことから有効な方法であり，イグサ（齋藤 2004），イン ゲンマメ（紙谷ら 2004）で開発されている。 また，イネ では改正 JAS 法の品種名等の表示義務化により，他品種 混入拉よび不正表示防止のために DNA マーカーによる 品種識別技術が開発されている（大坪ら 2002, 新村ら 2005). イチゴの品種識別技術については, CAPS (Cleaved Amplified Polymorphic Sequence）法による国内外 64 品種 の識別技術が開発され (Kunihisa et al. 2003，2005), 検 查機関ですでに利用されている.さらに, SSR（Simple Sequence Repeat) 法や AFLP（Amplified Fragment Length
Polymorphism) 法による国内 10 品種の識別技術も報告さ れている (Shimomura et al. 2006, 下村ら 2005). しかし, CAPS 法やAFLP 法では制限酵素処理を必要とするため にコスト扎よび時間という問題が残る。そこで，より簡 便な方法により特定のイチゴ品種の久を識別する技術が 開発されている。野村ら（2005）は，RAPD（Random

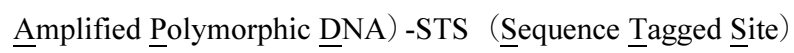
法拉よび $\beta$-ガラクタナーゼ遺伝子より設計したプライ マーにより, ‘アスカルビー’ のみを 25 品種・系統の中 から識別できるマルチプレックス PCR プライマーセット を開発している.筆者らも RAPD-STS 法抢よびAFLP-STS 法により，栃木県育成品種 ‘とち扣とめ’扣よび‘とち ひめ’の久を 25 品種・系統の中から識別できるマルチプ レックス PCR プライマーセットを開発している（田嵭ら 2008).

今回, 日本国内に流通する主要イチゴ品種を簡易かつ 効率的に識別するために, 制限酵素処理を必要としない RAPD-STS マーカーによるマルチプレックス PCR プライ マーセットの開発を試みた。 その結果, ‘とち扔とめ’打 よび“とちひめ’識別用マルチプレックス PCR プライマー セット（田㟝ら 2008）を加えた 3 七ットからなるマルチ プレックス PCR プライマーセットを開発し, 国内主要 8 品種を含む 25 品種・系統の識別が可能となったので報告 する.

\section{2. 材料および方法}

\section{1）供試材料}

国内作付面積上位 8 位までのイチゴ品種, ‘とち括と

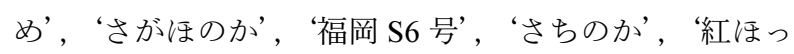
ぺ, ‘とよのか’, ‘章姫”, ‘女峰’に“とちひめ’, ‘杤 
の峰”, ‘久留米 49 号’, ‘麗紅’, ‘はるのか’, ‘レッド パール’, ‘濃姫”, ‘アスカルビー’, ‘メイヒャン（韓国 育成品種)’, “熊研い548（ひのしずく），“さつま抏と め’, ‘サンチーゴ’, ‘とね汪っぺ’, ‘やよいひめ’, “宝 交早生’, “アスカウェイブ' 执よび ‘とちひとみ’を加 えた計 25 品種・系統を供試した. 供試品種のらち, 福岡 県農業総合試験場から ‘福岡 S6 号’, 奈良県農業技術セ ンターから‘アスカルビーををポット苗で分譲していた だいた。 ‘メイヒャン’については，忠南農村振興院論山 イチゴ試験場から葉を提供していただいた. その他 22 品 種・系統は，栃木県農業試験場栃木分場の品種保存苗を 使用した。

\section{2）DNA 抽出および STS 化プライマーの設計}

DNA 抽出は, 各品種の葉片 $1.0 \mathrm{~g}$ を粉砕後, Yamamoto et al. (2001) の改変 CTAB 法により行った. STS 化する RAPD マーカーは, 467 種類のランダムプライマーによ る 16 品種・系統（‘とち拈とめ’, ‘とちひめ’, ‘女峰”, ‘久留米 49 号’, ‘栃の峰”, ‘麗紅’, ‘さちのか’, ‘とよ のか’, ‘はるのか’, ‘章姫”, “紅ほっぺ’, ‘レッドパー ル’，“濃姫”，“アスカルビー， ‘福岡 S6 号”，“さがほ のか’) 間の多型データをもとに選抜した（田㟝ら 2008）. STS プライマーの設計和よび作製したSTS 化プライマー によるバンドの再現性についても既報（田㟝ら 2008）の 方法に従った. ただし, E28-STS プライマーについては, PCR の際, プライマー濃度を $0.38 \mu \mathrm{M}$ とした.
3）マルチプレックス PCR プライマーセットの作製

マルチプレックス PCR プライマーセットには, 7 組の STS 化プライマー（A31-STS，B22-STS， C29-STS, E28STS，OPC12-STS，OPE3-STS，OPD7-STS）を用いた（表 1). ‘とち扎とめ’抽゙ ‘とちひめ’識別用マルチプ レックス PCR プライマーセット（田垴ら 2008）をプラ イマーセット1 1 とし, OPC12-STS, A31-STS, C29-STS, OPE3-STS の 4 組のプライマーをプライマーセット 2, E28-STS, OPD7-STS, B22-STS の 3 組のプライマーをプ ライマーセット 3 とした（表 1). この 3 セットのプライ マーセットを用い, RAPD マーカー選抜に使用した 16 品 種・系統に 9 品種（‘メイヒャン’, “熊研い548’, ‘さつ ま技とめ’, ‘サンチーゴ’, ‘と衩っぺ’, ‘よいひめ’, “宝交早生”，“アスカウェイブ’，“とちひとみ’）を加光 た 25 品種・系統のバンドパターンの検出を行った. PCR 組成は, 鋳型 DNA $50 \mathrm{ng}, \mathrm{rTaq} 1 \mathrm{U}$ (タカラバイオ社), $1 \times$ PCR Buffer (タカラバイオ社), $0.2 \mathrm{mM}$ dNTP Mixture (タカラバイオ社), 各濃度のフォワードおよびリバース プライマー（プライマーセット 1:0.50 $\mathrm{MM}$ E89-STS, $0.25 \mu \mathrm{M}$ A72-STS, $0.25 \mu \mathrm{M}$ EcoRI-ACA/MseI-CGG-STS, プ ライマーセット $2: 0.25 \mu \mathrm{M}$ OPC12-STS, $0.50 \mu \mathrm{M}$ A31STS, $0.50 \mu \mathrm{M}$ C29-STS, $0.50 \mu \mathrm{M}$ OPE3-STS, プライマー セット $3: 0.15 \mu \mathrm{M}$ E28-STS, $0.25 \mu \mathrm{M}$ OPD7-STS, $0.25 \mu \mathrm{M}$ B22-STS）とし, 液全量を $20 \mu \mathrm{L}$ とした. 増幅反応は, サー マルサイクラー（DNA Engine Tetrad PTC-225, MJ Japan 社）を用いて行った．反応条件は， $95^{\circ} \mathrm{C} て ゙ 5$ 分間熱変性 後, $94^{\circ} \mathrm{C}$ で 30 秒間, $59^{\circ} \mathrm{C}$ (プライマーセット 1) または

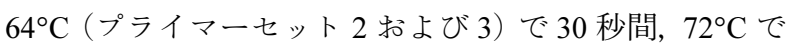

表 1. イチゴ 25 品種・系統識別用 STS 化プライマーの塩基配列持よびアニーリング温度

\begin{tabular}{|c|c|c|c|c|c|}
\hline $\begin{array}{l}\text { マルチプレックス PCR } \\
\text { プライマーセット名 }\end{array}$ & プライマ & 一名 & 塩基配列 & $\begin{array}{c}\text { アニーリング温度 } \\
\left({ }^{\circ} \mathrm{C}\right)\end{array}$ & $\begin{array}{l}\mathrm{PCR} \text { 産物 } \\
(\mathrm{bp}) * 2)\end{array}$ \\
\hline \multirow{3}{*}{$\begin{array}{c}\text { プライマーセット } 1 \text { *1) } \\
\text { (とちおとめ・とちひめ識別用) }\end{array}$} & E89-STS & $\begin{array}{l}\text { forward } \\
\text { reverse }\end{array}$ & $\begin{array}{l}\text { TAgACAAgAATgCCgTTTgA } \\
\text { ggCgACATAgTATACATAgA }\end{array}$ & 59 & $\mathrm{a}(1550)$ \\
\hline & $\begin{array}{l}\text { EcoRI-ACA/ } \\
\text { MseI-CGG-STS }\end{array}$ & $\begin{array}{l}\text { forward } \\
\text { reverse }\end{array}$ & $\begin{array}{l}\text { TTTTCATCTTAgCTggAggT } \\
\text { TTAACggCgTgTATgAATAg }\end{array}$ & 61 & b (310) \\
\hline & A72-STS & $\begin{array}{l}\text { forward } \\
\text { reverse }\end{array}$ & $\begin{array}{l}\text { TACgATTCgTgTATggTTAT } \\
\text { TACCCgAAATTAgAAggATT }\end{array}$ & 59 & c (202) \\
\hline \multirow{4}{*}{ プライマーセット 2} & OPC-12-STS & $\begin{array}{l}\text { forward } \\
\text { reverse }\end{array}$ & $\begin{array}{l}\text { gCCTTCTTCTgTACgCCATT } \\
\text { CCTCgATCgAACTCgTCAAT }\end{array}$ & 65 & $\mathrm{~d}(1150)$ \\
\hline & A31-STS & $\begin{array}{l}\text { forward } \\
\text { reverse }\end{array}$ & $\begin{array}{l}\text { CgACCgTACTCTTCCATCTTT } \\
\text { TggTATCCgTTgAgAgCgTA }\end{array}$ & 65 & e (921) \\
\hline & C29-STS & $\begin{array}{l}\text { forward } \\
\text { reverse }\end{array}$ & $\begin{array}{l}\text { AAgCgATCgAgTAgAgTgAg } \\
\text { gCCTTACCAAAACTAAACCAg }\end{array}$ & 65 & $f(613)$ \\
\hline & OPE3-STS & $\begin{array}{l}\text { forward } \\
\text { reverse }\end{array}$ & $\begin{array}{l}\text { CgCAACAgACCCCTTCTTTA } \\
\text { gATgCACACAAACACCAACC }\end{array}$ & 65 & $\mathrm{~g}(285)$ \\
\hline \multirow{3}{*}{ プライマーセット 3} & E28-STS & $\begin{array}{l}\text { forward } \\
\text { reverse }\end{array}$ & $\begin{array}{l}\text { AggCgTgCTgCAgATTAAAg } \\
\text { CCTCAAgCATTCAAgCCTTC }\end{array}$ & 66 & h (457) \\
\hline & OPD7-STS & $\begin{array}{l}\text { forward } \\
\text { reverse }\end{array}$ & $\begin{array}{l}\text { TggCACgggCTATAAgTTTC } \\
\text { gggTgCgCTCTATCATTTTC }\end{array}$ & 65 & $\mathrm{i}(381)$ \\
\hline & B22-STS & $\begin{array}{l}\text { forward } \\
\text { reverse }\end{array}$ & $\begin{array}{l}\text { ggAgTTggCTgTggAATgTT } \\
\text { TggACTTCCCCTTAACTTgC }\end{array}$ & 66 & $\mathrm{j}(312)$ \\
\hline
\end{tabular}

*1)：田㠃ら (2008) より引用.

*2) : E89-STS 抢よび OPC12-STS は電気泳動より PCR 増幅産物を推定した。他の PCR 産物はSTS 化バンドの塩基配列より決定した. 
1 分間を 1 サイクルとして 35 回繰り返し, 最後に $72^{\circ} \mathrm{C}$ で 7 分間伸長反応を行った. 電気泳動およびバンドの検 出は，田㟝ら（2008）に従った. なお，識別に使用する バンドの上にダミーのバンドが出現した場合は，明瞭な バンドのみを識別に使用した.

\section{3. イチゴ品種識別用RAPDマーカーの選抜とSTS化}

イチゴ 16 品種・系統間で明瞭な多型を示した RAPD マーカーについて STS 化を試みた結果, 安定した品種間 多型が得られる 7 組の STS 化プライマー(A31-STS, B22-
STS, C29-STS, E28-STS, OPC12-STS, OPE3-STS, OPD7STS)が作製でき，マルチプレックス PCR プライマーセッ ト用に選定した（図 1).A31-STS プライマーについて は, RAPD マーカーと異なるバンドパターンを示したが, 増幅が安定しているため選定した. 7 組の STS 化プライ マーによる 16 品種・系統間のバンドパターンを比較した

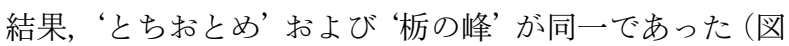
1).さらに, 9 品種を加えた 25 品種・系統間についてバ ンドパターンを比較した結果, “とね泣っぺ’および‘や よいひめ’についても同一であった（図 2-B，C，表 2). そのため, ‘とち扣とめ’と“栃の峰”, ‘と枚っへ’ と

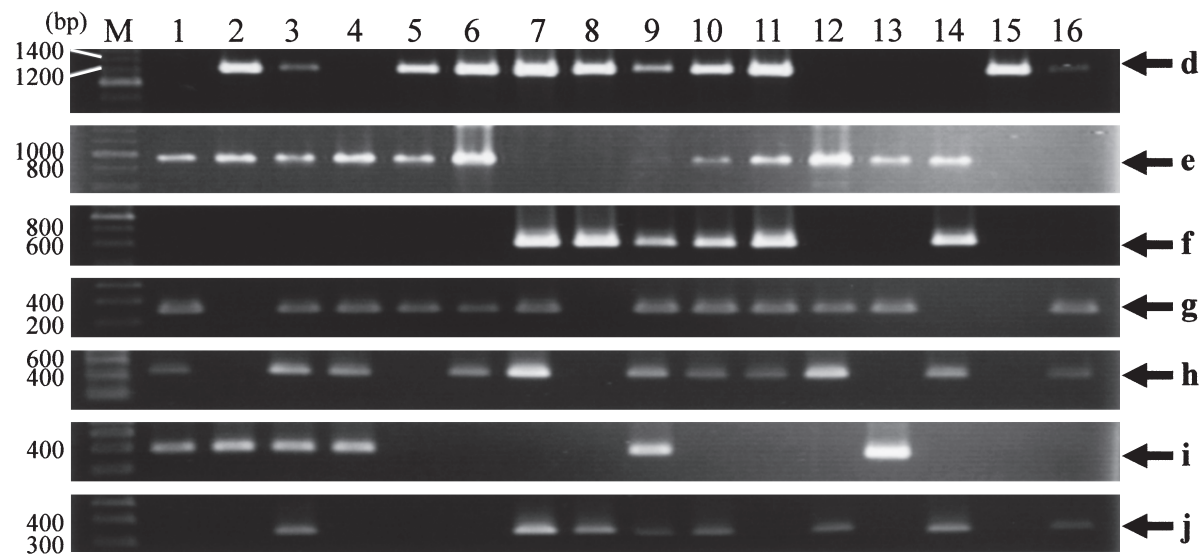

図 1. イチゴ品種識別 STS 化プライマーによる電気泳動結果

1:とち抢とめ, $2:$ とちひめ, 3 :女峰, $4:$ 栃の峰, 5 : 久留米 49 号, $6:$ 麗紅, $7:$ さち

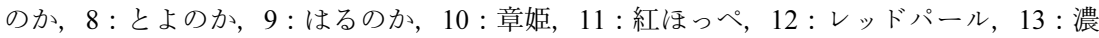
姫, $14:$ アスカルビー, $15:$ 福岡 S6 号, 16 : さがほのか

$\mathrm{M}$ : 分子量マーカー (200 bp ladder)

d:OPC12-STS, e :A31-STS, f:C29-STS, g:OPE3-STS, h:E28-STS, i:OPD7-STS, j:B22-STS

A)
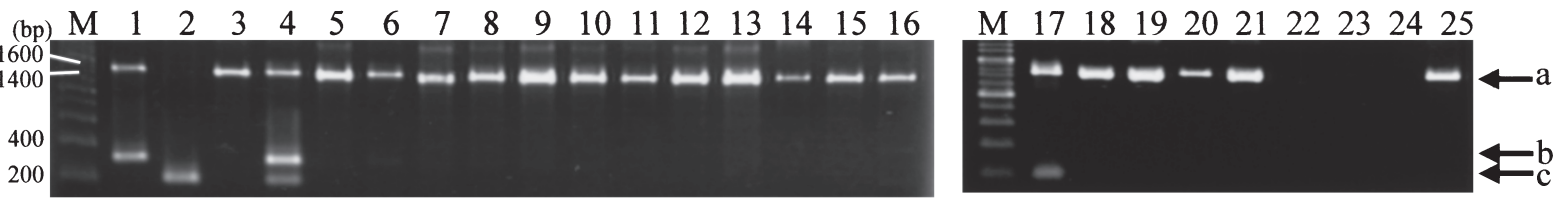

B)
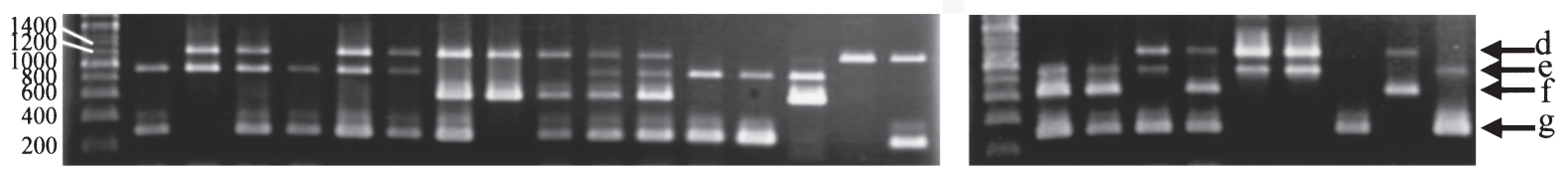

C)
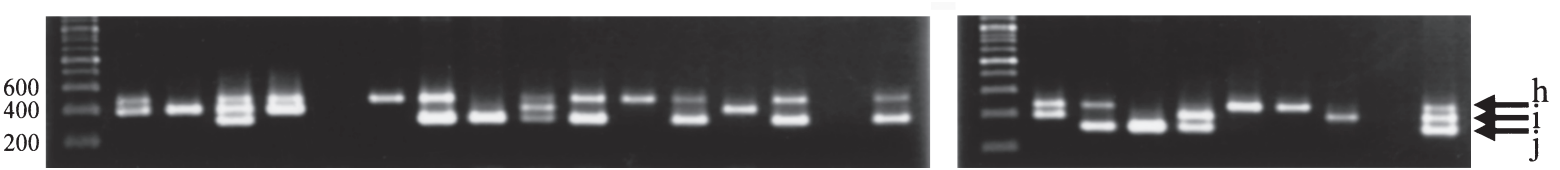

図 2. イチゴ品種識別用マルチプレックス PCR プライマーセット 1 ～ 3 による電気泳動結果

A）: プライマーセット 1, B)：プライマーセット 2, C) : プライマーセット 3

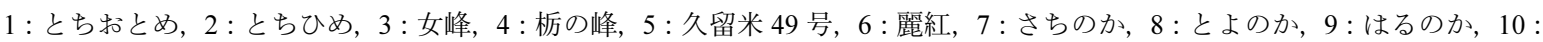
章姫, 11 : 紅ほっぺ, 12:レッドパール，13:濃姫，14：アスカルビー, 15:福岡 S6 号, 16:さがほのか, 17：メイヒャン，

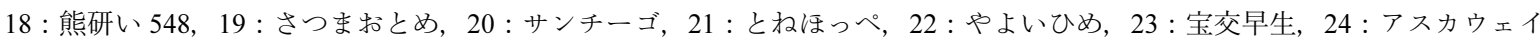
ブ，25：とちひとみ

M : DNA 分子量マーカー (200 bp ladder)

a : E89-STS, b : EcoRI-ACA/MseI-CGG-STS, c : A72-STS, d : OPC12-STS, e : A31-STS, f : C29-STS, g : OPE3-STS, h : E28STS, i : OPD7-STS, j: B22-STS 
‘やよいひめ’を識別できる‘とち括とめ’および ‘とち ひめ’識別用マルチプレックス PCR プライマーセット（田 㟝ら 2008）を合わせて用いることとした（表 1，2，以後 プライマーセット 1 と記す).

\section{4. イチゴ品種識別用マルチプレックスPCRプライ マーセットの開発}

7 組の STS 化プライマーは, 増幅産物の視認性を考慮 し, OPC12-STS (1150 bp), A31-STS (921 bp), C29-STS (613 bp), OPE3-STS（285 bp）の 4 組のSTS 化プライ マーで構成されるプライマーセット2（表 1), E28-STS (457bp), OPD7-STS (381 bp), B22-STS (312 bp) の 3 組の STS 化プライマーで構成されるプライマーセット 3 （表 1）に2 分割した. 3 種類のプライマーセットを用い てマルチプレックス PCR によるイチゴ 25 品種・系統を 識別した結果, すべての品種・系統が異なるバンドパター ンを示し, 識別することが可能となった（図 2, 表 2). 供 試品種・系統のうち, “熊研い548’, ‘やよいひめ’, “濃 姫’，“アスカルビー’ の国内全作付面積に抢ける割合は, 各 $1.3 \%, 1.0 \%, 1.0 \%, 1.0 \%$ であり（2007 年度 JA 全農 調べ), 主要 8 品種およびこれら 4 品種を合わせた国内作 付面積の割合は約 $95 \%$ に達する. そのため, 本プライマー セットは，育成者権の保護とともに国内市場に流通する イチゴの検査にも有用であると考兄られる.

プライマーセットの組合せによる識別可能なイチゴ品
種数は, プライマーセット $1: 4$ 品種, プライマーセット $2: 4$ 品種, プライマーセット $3: 1$ 品種, プライマーセッ 卜 1 拈よび $2: 13$ 品種, プライマーセット 1 拈よび $3: 10$ 品種, プライマーセット 2 捛よび $3: 21$ 品種であった（表 3). 25 品種・系統内で特定の品種の及を識別したい場合 は, 1〜2のプライマーセットを用いることで可能となっ た. 例えば， “福岡 S6 号”を識別する場合はプライマー セット 2 を, ‘さちのか’を識別する場合は, プライマー 2 打よび 3 を使用すれば識別できる。 これは，育成者権 の保護以外飞も, 栽培品種が限られている原苗生産, 栽 培戋場和よび流通加工段階に抢ける他品種混入防止, 偽 装表示防止に执いて効率的に品種識別ができるものと考 えられる。

検査サンプルとしては，主に市販成熟果実を想定され るが, 成熟果実には多糖類等の夾雑物が多く含まれるた め, PCR に利用できる DNA の抽出が難しいことが知ら 孔ている (Mercado et al. 1999). しかし，筆者らは，す でに, Yamamoto et al.（2001）の方法によりイチゴ成熟 果実(颌片拉よび花托) からの DNA 抽出を可能とし, 識 別バンドの増幅も確認しているため（田㠃ら 2008）, 成 熟果実に打ける品種識別についても本方法により問題な く対応できる.

開発した国内主要イチゴ品種識別用マルチプレックス PCR プライマーセットは, 3 セッの PCR 拈よびアガロー ス電気泳動により国内主要イチゴ 25 品種·系統識別でき ることから，目的である操作性の簡易化また低コスト化

表 2. イチゴ 25 品種・系統間に打ける各マルチプレックス PCR プライマーセットを用いたバンドの有無

\begin{tabular}{|c|c|c|c|c|c|c|c|c|c|c|}
\hline \multirow{3}{*}{$\begin{array}{c}\text { 品種・系統名/ } \\
\text { プラマー名拈よび } \\
\text { 分子量 }(\mathrm{bp})\end{array}$} & \multicolumn{3}{|c|}{ プライマーセット $1 * 1)$} & \multicolumn{4}{|c|}{ プライマーセット 2} & \multicolumn{3}{|c|}{ プライマーセット 3} \\
\hline & E89-STS & $\begin{array}{c}\text { EcoRI-ACA/ } \\
\text { MseI-CGG-STS }\end{array}$ & A72-STS & OPC-12-STS & A31-STS & C29-STS & OPE3-STS & E28-STS & OPD7-STS & B22-STS \\
\hline & 1550 & 310 & 202 & 1150 & 921 & 613 & 285 & 457 & 381 & 312 \\
\hline 1 とち扣とめ & + & + & - & - & + & - & + & + & + & - \\
\hline 2 とちひめ & - & - & + & + & + & - & - & - & + & - \\
\hline 3 女峰 & + & - & - & + & + & - & + & + & + & + \\
\hline 4 栃の峰 & + & + & + & - & + & - & + & + & + & - \\
\hline 5 久留米 49 号 & + & - & - & + & + & - & + & - & - & - \\
\hline 6 麗紅 & + & - & - & + & + & - & + & + & - & - \\
\hline 7 さちのか & + & - & - & + & - & + & + & + & - & + \\
\hline 8 とよのか & + & - & - & + & - & + & - & - & - & + \\
\hline 9はるのか & + & - & - & + & - & + & + & + & + & + \\
\hline 10 章姫 & + & - & - & + & + & + & + & + & - & + \\
\hline 11 紅ほっぺ & + & - & - & + & + & + & + & + & - & - \\
\hline 12 レッドパール & + & - & - & - & + & - & + & + & - & + \\
\hline 13 濃姫 & + & - & - & - & + & - & + & - & + & - \\
\hline 14 アスカルビー & + & - & - & - & + & + & - & + & - & + \\
\hline 15 あま扬ら & + & - & - & + & - & - & - & - & - & - \\
\hline 16 さがほのか & + & - & - & + & - & - & + & + & - & + \\
\hline 17 メイヒャン & + & - & + & - & + & + & + & + & + & - \\
\hline 18 熊研い 548 & + & - & - & - & + & + & + & + & - & + \\
\hline 19 さつま扔とめ & + & - & - & + & + & - & + & - & - & + \\
\hline 20 サンチーゴ & + & - & - & + & - & + & + & - & + & + \\
\hline 21 と衫ほっぺ & + & - & - & + & + & - & - & + & - & - \\
\hline 22 やよいひめ & - & - & - & + & + & - & - & + & - & - \\
\hline 23 宝交早生 & - & - & - & - & - & - & + & - & + & - \\
\hline 24 アスカウェイブ & - & - & - & + & - & + & - & - & - & - \\
\hline 25 とちひとみ & + & - & - & - & + & - & + & + & + & + \\
\hline
\end{tabular}

*1)：田㠃ら（2008）より引用.

*2) : +はバンド有, 一はバンド無を示す. 
表 3. マルチプレックス PCR プライマーセットの組み合わせによる識別可能なイチゴ品種・系統

\begin{tabular}{|c|c|c|}
\hline $\begin{array}{c}\text { マルチプレックス PCR プライマーセット } \\
\text { の組み合わせ }\end{array}$ & 識別可能品種数 & 品種名 * \\
\hline プライマーセット 1 & 4 & とちおとめ, とちひめ, 杤の峰, メイヒャン \\
\hline プライマーセット 2 & 4 & さがほのか, 福岡 S6 号, アスカルビー, 宝交早生 \\
\hline プライマーセット3 & 1 & サンチーゴ \\
\hline プライマーセット $1 \cdot 2$ & 13 & $\begin{array}{l}\text { とちおとめ, さがほのか, 福岡 S6 号, とょのか, 熊研い548, やよいひ } \\
\text { め, アスカルビー, とちひめ, 栃の峰, メイヒャン, 宝交早生, とねほ } \\
\text { ペ, アスカウェイ゙ }\end{array}$ \\
\hline プライマーセット $1 \cdot 3$ & 10 & 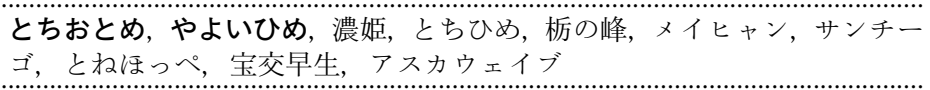 \\
\hline プライマーセット $2 \cdot 3$ & 21 & 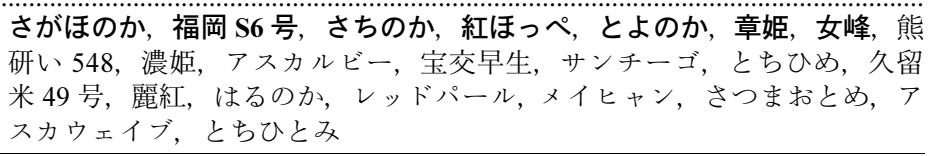 \\
\hline プライマーセット $1 \cdot 2 \cdot 3$ & 25 & 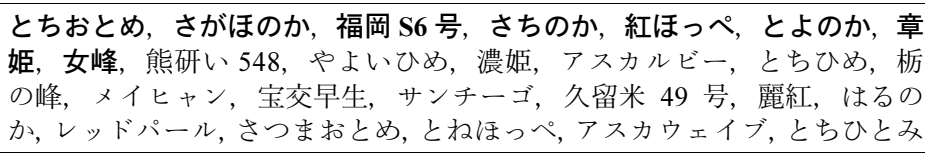 \\
\hline
\end{tabular}

* : 太文字は国内作付け面積上位イチゴ 8 品種

が図れた。 また，イネの品種判別（大坪ら 2002，新村ら 2005）には，RAPD-STS 法およびマルチプレックス PCR 法が広く普及して扣り，本イチゴ品種識別方法は実用性 が高いと考えられる。

\section{謝 辞}

本研究の一部は，農林水産省の先端技術を活用した農 林水産研究高度化事業に打ける「野菜・茶・ウメの原産 地表示判別技術の開発プロジェクト」（2001-2004）の中 で実施された。本研究を遂行するにあたり，サンプルの 提供抢よび貴重な御助言をいただいた（独）農業・食品 産業技術総合研究機構 野菜茶業研究所松元哲博士ならび に國久美由紀氏，奈良県農業技術七ンター 浅尾浩史博士 ならびに野村貴浩氏，福岡県農業総合試験場下村克己氏 に厚く感謝申し上げます。また快くサンプルを提供して いただいた忠南農村振興院論山イチゴ試験場 金泰日博士 ならびに栃木県農業試験場栃木分場に感謝申し上げます. また，実験で多大なるご協力をいただいた栃木県農業試 験場生物工学部阿久津操氏に感謝致します.

\section{引用文献}

FAO (2007) FAOSTAT http://faostat.fao.org/
JA 全農（2007）H20 年産いちご主産県協議会資料 紙谷元一 - 竹内 徹 - 楠目俊三 (2004) 育種学研究 6: 29-32.

Kunihisa, M., N. Fukino and S. Matsumoto (2003) Euphytica 134: 209-215.

Kunihisa, M., N. Fukino and S. Matsumoto (2005) Theor. Appl. Genet. 110: 1410-1418.

Mercado, J.A., I. El Mansouri, S. Jiménez-Bermúdez, F. PliegoAlfaro and M.A. Quesada (1999) In Vitro Cell. Dev. Biol. Plant 35: $152-153$.

野村貴浩・天谷正行・田㠃公久・楠本憲一・浅尾浩史（2005）近 畿中国四国農研究 7: 37-40.

農林水産省 (2007) 品種登録ホームページ http://www.hinsyu.maff. go.jp/

大坪研一.中村澄子. 今村太郎 (2002) 日本農芸化学会誌 76: 388397.

齋藤＼cjkstart彰（2004）農業および園芸 79: 168-174.

下村克己·三井寿一・藤田幸一・佐藤公洋 (2005) 福岡県農業総 合試験場研究報告 24: 43-47.

Shimomura, K. and K. Hirashima (2006) J. Japan Soc. Hort. Sci. 75: 399-402.

新村和則・金川 寛·三上隆司・福森 武 (2005) 育種学研究 7: 87-94.

竹次 稔（2004）農業打よび園芸 79: 199-204.

田嵭公久 - 柏谷祐樹 - 小林俊一 · 天谷正行 (2008) DNA 多型 16: 119-128.

Yamamoto, T., T. Kimura, Y. Sawamura, K. Kotobuki, Y. Ban, T. Hayashi and N. Matsuta (2001) Theor. Appl. Genet. 102: 865870 . 